\title{
Estimation of genetic parameters for litter size after natural and hormone-induced oestrus in sheep
}

\author{
M. Baelden ${ }^{\mathrm{a}}$, L. Tiphine ${ }^{\mathrm{b}}$, J.P. Poivey ${ }^{\mathrm{c}}$, J. Bouix ${ }^{\mathrm{a}}$, B. Bibé ${ }^{\mathrm{a}}$, C. Robert-Granié ${ }^{\mathrm{a}}$, L. Bodin ${ }^{\mathrm{a}, *}$ \\ aINRA, Station d'Amélioration Génétique des Animaux, BP52627, 31326 Castanet-Tolosan, France \\ bInstitut de l'Elevage, Département génétique, 149 rue de Bercy, 75595 Paris Cedex 12, France \\ ${ }^{\mathrm{c}}$ CIRAD, Campus international de Baillarguet, 34398 Montpellier, France
}

Received 6 October 2004; received in revised form 26 April 2005; accepted 13 May 2005

\begin{abstract}
Genetic parameters for litter size after natural and hormone-induced oestrus were estimated for Ovin Ile de France, Blanc du Massif Central and Mouton Vendéen sheep, using REML methods in animal and sire model BLUP for observed litter size and normal scores of litter size. Litters born after hormone-induced oestrus and after natural oestrus were treated as different traits in order to estimate the genetic correlation between the traits and the genetic parameters of each trait. Explanatory variables were the year*flock* season of lambing effect, the physiological condition factor combining the type of rearing, age at the first lambing, interval between lambings and number of lambs suckled at the previous lambing, the month of birth nested within gestation number, a permanent environmental effect associated with the ewe and the additive genetic effect (sire or animal effect). For the three breeds, the heritability estimates for natural litter size, equal to 0.10 , was higher than the heritability estimates for induced litter size, equal to 0.06 . The estimate of genetic correlation between the two fertilization types was closed to 0.75 . This result suggests that natural and induced litter size can be considered as two different traits, although controlled by a great number of common genes. This genetic correlation was higher than the previous estimate (0.40) reported by Bodin (1979) [Bodin, L., 1979. Estimation des paramètres génétiques de la taille de portée des agnelles Lacaune après fécondation sur oestrus naturel et induit. Ann. Génét. Sél. Anim. 11 (4), 413-424].
\end{abstract}

(c) 2005 Elsevier B.V. All rights reserved.

Keywords: Sheep; Genetic parameters; Litter size; Hormone-induced oestrus; Natural oestrus

\section{Introduction}

Litter size is one of the most important components of profitability of meat sheep: it has a greater affect on

\footnotetext{
* Corresponding author. Tel.: +33 5612852 73; fax: +33 561285353 .

E-mail address: bodin@toulouse.inra.fr (L. Bodin).
}

the variability of the weight of weaned lambs per ewe than does the individual growth of the lambs. For some breeding schemes of meat sheep, litter size is one of the main selection objectives. The use of hormonal treatments, (such as a vaginal sponge impregnated with a synthetic analogue of progesterone inserted in the ewe vagina for a 12- or 14-day period 
with a PMSG injection at withdrawal), which is required for a better reproduction management and an efficient set up of selection program, affects prolificacy. At the present time, in the French genetic evaluation of prolificacy, two different breeding values are estimated for each animal: one for prolificacy after natural oestrus (NO) and another for prolificacy after induced oestrus (IO). These estimations are based on genetic parameters available when this evaluation was set up in 1992 (Institut de l'Elevage, 1995). They were estimated on the Lacaune breed as 0.10 and 0.08 for the heritability of litter size after natural and induced oestrus, respectively; 0.20 and 0.15 for the repeatability of litter size after natural and induced oestrus, respectively; and 0.40 for the genetic correlation between these traits (Bodin, 1979).

The objective of this study was to estimate new values of genetic parameters for prolificacy and specifically the genetic correlation between natural and induced litter size, in order to optimise selection for overall prolificacy.

\section{Materials and methods}

\subsection{Animals}

Three breeds (Ovin Ile de France (OIF), Blanc du Massif Central (BMC) and Mouton Vendéen (VEN)) were considered in this study. Their characteristics are presented in Table 1. Data was from the French National performance recording scheme (French National database). This database includes pedigree information and performance data on prolificacy collected from 1982 to 2002. For each ewe, the number of lambs born, the date of lambing, the flock number, the season of lambing, the gestation number and the type of reproduction (natural or induced oestrus) are recorded. The database also includes information about the birth of the ewe: birth date, type of birth (single, twin and triplet) and the type of rearing (single, twin, triplet or artificial rearing). For the three breeds, litter size ranged from 1 to 8 , but for the study, only 5 classes were considered, the last class included litter size equal to 5 and more. Ewes with incomplete performance records, ewes lacking birth information and records with other obvious errors were removed.

In the original data set, the occurrence of oestrus type per ewe and the number of ewes per sire was not optimal for estimation of genetic parameters, so different subsets were generated for each breed to verify the stability of the results whatever the design (i.e. family size, number of sire families, etc.).

- To estimate the heritability, independent data sets were created for prolificacy after natural and induced oestrus. Reduced data sets were created by keeping only the performance of sire families with at least 30 half-sibs having records in natural oes-

Table 1

Characteristics of the studied breeds (year 2002)

\begin{tabular}{|c|c|c|c|c|}
\hline & & Ovin Ile de France & Blanc du Massif Central & Mouton Vendéen \\
\hline \multicolumn{2}{|l|}{ Total livestock } & 240,000 females & 300,000 females & 250,000 females \\
\hline \multicolumn{2}{|l|}{ Controlled livestock } & 28,151 females & 36,760 females & 10,093 females \\
\hline \multicolumn{2}{|c|}{ Number of controlled farms } & 165 & 113 & 55 \\
\hline \multicolumn{2}{|l|}{ Breeding system } & Shed's breed & Hardy breed & Grazier breed \\
\hline \multicolumn{2}{|l|}{ Lambing period } & $\begin{array}{l}\text { Autumn principally } \\
\text { and spring }\end{array}$ & $\begin{array}{l}\text { Winter spring summer } \\
\text { (fast reproduction rhythm) }\end{array}$ & Autumn and spring \\
\hline \multirow{2}{*}{$\begin{array}{l}\text { Prolificacy after natural } \\
\text { oestrus }\end{array}$} & Lambing before 19 months & 1.50 & 1.32 & 1.55 \\
\hline & Lambing after 19 months & 1.68 & 1.43 & 1.70 \\
\hline \multirow{2}{*}{$\begin{array}{l}\text { Prolificacy after induced } \\
\text { oestrus }\end{array}$} & Lambing before 19 months & 1.66 & 1.56 & 1.76 \\
\hline & Lambing after 19 months & 1.83 & 1.62 & 1.87 \\
\hline \multicolumn{2}{|c|}{ Number of lambings after induced oestrus } & $2515(16 \%)$ & $4560(13 \%)$ & $1559(16 \%)$ \\
\hline \multicolumn{2}{|c|}{ Number of lambings with known paternity } & $10,837(69 \%)$ & $10,274(29 \%)$ & $7875(83 \%)$ \\
\hline \multirow{2}{*}{\multicolumn{2}{|c|}{ Selection scheme }} & Maternal aptitudes & Maternal aptitudes & Maternal aptitudes \\
\hline & & Meat purpose & Meat purpose & Meat purpose \\
\hline
\end{tabular}

From: Institut National de la Recherche Agronomique, Institut de l'Elevage, France Upra Sélection (2003). 
trus $\left(30_{\mathrm{NO}}\right)$ and in induced oestrus $\left(30_{\mathrm{IO}}\right)$. Less severe, but larger data sets were also considered by keeping the performances of sire families with at least 15 and 10 half-sibs having records in natural oestrus $\left(15_{\mathrm{NO}}\right.$ and $10_{\mathrm{NO}}$, respectively) and in induced oestrus $\left(15_{\mathrm{IO}}\right.$ and $10_{\mathrm{IO}}$, respectively).

- To estimate the genetic correlation, subsets with the performances of sire families with at least 30 halfsibs having at least one lambing after natural oestrus and at least 30 half-sibs having at least one lambing after induced oestrus (data set " $30_{\mathrm{NO}}$ and 30 IO") were generated. Less severe data sets were created with performances of smaller sire families with at least 15 and 10 half-sibs in each oestrus type (data sets " $15_{\mathrm{NO}}$ and $15_{\mathrm{IO}}$ " and " $10_{\mathrm{NO}}$ and 10 IO"). The number of records for each data set and each breed studied are presented in Table 2 .

- To estimate genetic parameters at different parities, the same data sets were used but they were split in three parts based on gestation number: one subset with the first lambing data, one with the second lambing data and one with data of the later lambings.

- To estimate more accurately the additive genetic and the permanent environmental effects, a data set with more severe restrictions on ewe data was considered by using sire families with at least 40 half-sibs having at least 4 lambings after natural oestrus (" $40_{\mathrm{NO}-4 \mathrm{~L}}$ ).

\subsection{Models}

To estimate variance components, linear mixed model methodology was used on litter size and normal scores (transformed variables) (Poivey et al., 1990, 1994). Litters born after induced oestrus and after natural oestrus were treated as different traits in order to estimate the genetic parameters. Using the mixed procedure of SAS (1999) and the VCE4 software (Groeneveld, 1998), univariate (one model for each oestrus type) and bivariate models with the REML (restricted maximum likelihood estimator, Patterson and Thompson, 1971) method were applied to an animal or a sire model. These linear mixed models included fixed effects routinely used in the French genetic evaluation of prolificacy in meat sheep, a permanent environmental effect associated with the ewe and the additive genetic effect (sire or animal effects). The interaction year* flock* season of lambing effect, a physiological condition factor and the month of birth nested within gestation number were taken into account in the fixed part of the model. The "physiological condition" factor represents a combination of type of rearing ( 3 classes: one single lamb, two or three lambs born per ewe), age at the first lambing, interval between lambings (eight classes depending on the gestation number) and number of lambs suckled at the previous lambing (Poivey et al., 1995).

Table 2

Number of lambings, ewes and sires in data sets selected for estimation of genetic parameters for litter size after natural (NO) and induced (IO) oestrus

\begin{tabular}{|c|c|c|c|c|c|c|c|c|c|c|}
\hline \multirow[t]{2}{*}{ Data sets ${ }^{\mathrm{a}}$} & \multirow[t]{2}{*}{$\begin{array}{l}\text { Type of } \\
\text { oestrus }\end{array}$} & \multicolumn{3}{|c|}{$\begin{array}{l}\text { Ovin Ile de France } \\
\text { number of }\end{array}$} & \multicolumn{3}{|c|}{$\begin{array}{l}\text { Blanc du Massif Central } \\
\text { number of }\end{array}$} & \multicolumn{3}{|c|}{$\begin{array}{l}\text { Mouton Vendéen } \\
\text { number of }\end{array}$} \\
\hline & & Lambings & Ewes & Sires & Lambings & Ewes & Sires & Lambings & Ewes & Sires \\
\hline \multirow[t]{2}{*}{$30_{\mathrm{NO}}$ and $30_{\mathrm{IO}}$} & $\mathrm{NO}$ & 30,652 & 10,470 & 80 & 66,026 & 15,733 & 139 & 39,741 & 13,431 & 169 \\
\hline & $\mathrm{IO}$ & 11,017 & 5773 & 80 & 14,989 & 9560 & 139 & 16,366 & 8520 & 169 \\
\hline \multirow[t]{2}{*}{$15_{\mathrm{NO}}$ and $15_{\mathrm{IO}}$} & $\mathrm{NO}$ & 52,073 & 17,456 & 274 & 98,792 & 24,267 & 354 & 83,299 & 27,951 & 598 \\
\hline & IO & 18,717 & 9852 & 274 & 22,030 & 12,937 & 354 & 32,982 & 17,263 & 598 \\
\hline \multirow[t]{2}{*}{$10_{\mathrm{NO}}$ and $10_{\mathrm{IO}}$} & $\mathrm{NO}$ & 72,599 & 24,148 & 554 & 117,610 & 28,717 & 526 & 105,136 & 35,419 & 957 \\
\hline & $\mathrm{IO}$ & 25,092 & 13,317 & 554 & 25,314 & 14,974 & 526 & 40,900 & 21,539 & 957 \\
\hline $30_{\mathrm{NO}}$ & NO & 71,637 & 23,651 & 395 & 106,647 & 27,354 & 401 & 88,822 & 29,968 & 558 \\
\hline $15_{\mathrm{NO}}$ & NO & 119,697 & 39,766 & 1183 & 139,697 & 35,355 & 785 & 131,852 & 44,890 & 1284 \\
\hline $10_{\mathrm{NO}}$ & $\mathrm{NO}$ & 138,725 & 46,486 & 1756 & 151,385 & 38,115 & 1016 & 147,549 & 50,370 & 1748 \\
\hline $30_{\mathrm{IO}}$ & $\mathrm{IO}$ & 12,954 & 6479 & 98 & 14,989 & 8560 & 139 & 16,366 & 8520 & 169 \\
\hline $15_{\mathrm{IO}}$ & $\mathrm{IO}$ & 21,373 & 10,778 & 315 & 22,053 & 12,952 & 355 & 33,346 & 17,438 & 609 \\
\hline $10_{\mathrm{IO}}$ & $\mathrm{IO}$ & 27,294 & 14,171 & 605 & 25,346 & 14,997 & 528 & 41,420 & 21,778 & 978 \\
\hline $40_{\mathrm{NO}}-4_{\mathrm{L}}$ & NO & 35,184 & 5841 & 199 & 77,224 & 11,012 & 254 & 45,010 & 7375 & 318 \\
\hline
\end{tabular}

\footnotetext{
${ }^{\text {a }}$ See text for data sets definition.
} 


\section{Results}

\subsection{Litter size}

The means and the variances of the litter size after natural and induced oestrus for the data set " $30_{\mathrm{NO}}$ and 30 IO" are presented in Table 3 for each breed.

The data set size of records after induced oestrus was smaller for all breeds because relatively few hormonal treatments are used (Table 2). However, the mean prolificacy was very stable among the different data sets within breed and within reproduction type. The average litter size after natural oestrus (1.42 in BMC, 1.64 in OIF and 1.75 in VEN) was lower than after induced oestrus (1.68 in BMC, 1.86 in OIF and 1.96 in VEN), but the variability of litter size after induced oestrus was higher. Its standard deviation (0.72 in BMC, 0.82 in OIF and 0.78 in VEN) was increased by about $30 \%$ compared to the standard deviation of litter size after natural oestrus $(0.55$ in $\mathrm{BMC}, 0.60$ in OIF and 0.64 in VEN).

Whatever the type of reproduction, the average litter size increased with parity in OIF and BMC breeds (Table 3). The mean natural prolificacy was increased by $2.5 \%$ in the second lambing and was increased by $8 \%$ between the second and the later lambings. This age effect was different after induced oestrus, since there was a higher increase between the first and second lambing (10\%) than between the second and the later lambings (2\%). Moreover, at

Table 3

Means $(\mu)$ and standard deviations $(\sigma)$ of the litter size after natural (NO) and induced oestrus (IO) for three French breeds and mean litter size for the first $\left(\mu_{\mathrm{LS} 1}\right)$, the second $\left(\mu_{\mathrm{LS} 2}\right)$ and later $\left(\mu_{\mathrm{LS} 3+}\right)$ lambings for the OIF and BMC breeds

\begin{tabular}{lllll}
\hline & $\begin{array}{l}\text { Type of } \\
\text { oestrus }\end{array}$ & $\begin{array}{l}\text { Ovin Ile } \\
\text { de France }\end{array}$ & $\begin{array}{l}\text { Blanc du } \\
\text { Massif Central }\end{array}$ & $\begin{array}{l}\text { Mouton } \\
\text { Vendéen }\end{array}$ \\
\hline$\mu$ & NO & 1.64 & 1.42 & 1.75 \\
$\sigma$ & & 0.60 & 0.55 & 0.64 \\
$\mu_{\text {LS1 }}$ & & 1.56 & 1.35 & \\
$\mu_{\text {LS2 }}$ & & 1.60 & 1.38 & \\
$\mu_{\text {LS3+ }}$ & & 1.73 & 1.50 & 1.96 \\
$\mu$ & IO & 1.86 & 1.68 & 0.78 \\
$\sigma$ & & 0.82 & 0.72 & \\
$\mu_{\text {LS1 }}$ & & 1.73 & 1.48 & \\
$\mu_{\text {LS2 }}$ & & 1.91 & 1.67 & \\
$\mu_{\text {LS3+ }}$ & & 1.93 & 1.73 & \\
\hline
\end{tabular}

each lambing, hormonal treatment resulted in an increase of prolificacy with the largest effect at the second lambing where the difference between natural and induced prolificacy reached $20 \%$.

\subsection{Heritability and repeatability}

Estimates of genetic parameters obtained from the different data sets were very similar for the three breeds and for both reproduction types. Sire and animal models gave also very similar estimated parameters. Estimates of genetic parameters made with the raw litter size or the normal score transformation were very stable. Because results were very similar, only estimates of genetic parameters of the data set " $30_{\mathrm{NO}}$ and $30_{\mathrm{IO}}$ " are presented in Table 4 for the three breeds. Results are shown for a univariate sire model and a bivariate animal model on raw litter size data, and for a bivariate animal model on normal score transformated data.

For the three breeds, heritability estimates were very low and similar within each fertilization type using animal or sire model (Table 4). Heritability of natural prolificacy $\left(h_{\mathrm{NO}}^{2}\right)$ ranged from 0.08 in OIF to 0.14 in VEN, while heritability of induced prolificacy $\left(h_{\mathrm{IO}}^{2}\right)$ was slightly lower, ranging from 0.05 in VEN to 0.07 in BMC and OIF. The standard errors ranged from 0.002 to 0.010 and were multiplied by two between the less severe data set " $10_{\mathrm{NO}}$ and $10_{\mathrm{IO}}$ " and the most severe one " $30_{\mathrm{NO}}$ and $30_{\mathrm{IO}}$ ".

Repeatability of the litter size after natural oestrus (equal to 0.12 for the three breeds) was slightly larger than the repeatability of the litter size after induced oestrus, ranging from 0.07 to 0.11 (Table 4). These differences in heritability and repeatability were mainly due to a lower residual variance for performance after a natural oestrus, whereas the genetic variance was generally higher for the induced prolificacy and the variance of permanent environmental effect were similar.

Heritability of litter size at each parity, which was estimated for OIF and BMC breeds, generally decreased when the ewe got older (Table 5). With natural oestrus, the heritability decreases slowly between the first and the third and later lambings. With induced oestrus, it was higher at the first lambing than at the second and higher at the second than at the subsequent lambings $(0.12,0.08$ and 0.05 in 
Table 4

Additive genetic $(\mathrm{V}(\mathrm{a}))$, animal permanent $(\mathrm{V}(\mathrm{P}))$ and residual $(\mathrm{V}(\mathrm{e}))$ variances, heritability $\left(h^{2}\right)$, genetic correlation $\left(r_{\mathrm{g}}\right)$ and repeatability of prolificacy after natural $(\mathrm{NO})$ and induced (IO) oestrus estimated with animal or sire, univariate or bivariate models on observed litter size and after normal score transformation of litter size

\begin{tabular}{|c|c|c|c|c|}
\hline Parameter & Model $^{\mathrm{a}}$ & Ovin Ile de France & Blanc du Massif Central & Mouton Vendéen \\
\hline \multirow[t]{3}{*}{$\mathrm{V}(\mathrm{a}) \mathrm{NO}$} & 1 & 0.03 & 0.03 & 0.05 \\
\hline & 2 & 0.03 & 0.03 & 0.04 \\
\hline & 3 & 0.05 & 0.06 & 0.07 \\
\hline \multirow[t]{3}{*}{ V(a) IO } & 1 & 0.04 & 0.04 & 0.03 \\
\hline & 2 & 0.04 & 0.03 & 0.03 \\
\hline & 3 & 0.05 & 0.04 & 0.04 \\
\hline \multirow[t]{3}{*}{$\mathrm{V}(\mathrm{P}) \mathrm{NO}$} & 1 & & & \\
\hline & 2 & 0.02 & 0.01 & 0.01 \\
\hline & 3 & 0.03 & 0.01 & 0.01 \\
\hline \multirow[t]{3}{*}{$\mathrm{V}(\mathrm{P}) \mathrm{IO}$} & 1 & & & \\
\hline & 2 & 0.03 & 0.01 & 0.02 \\
\hline & 3 & 0.04 & 0.02 & 0.02 \\
\hline \multirow[t]{3}{*}{$\mathrm{V}(\mathrm{e}) \mathrm{NO}$} & 1 & 0.31 & 0.27 & 0.37 \\
\hline & 2 & 0.28 & 0.25 & 0.33 \\
\hline & 3 & 0.58 & 0.58 & 0.63 \\
\hline \multirow[t]{3}{*}{$\mathrm{V}(\mathrm{e}) \mathrm{IO}$} & 1 & 0.64 & 0.50 & 0.58 \\
\hline & 2 & 0.58 & 0.46 & 0.54 \\
\hline & 3 & 0.72 & 0.7 & 0.75 \\
\hline \multirow[t]{3}{*}{$h_{\mathrm{NO}}^{2}$} & 1 & $0.09 \pm 0.006$ & $0.12 \pm 0.004$ & $0.14 \pm 0.005$ \\
\hline & 2 & $0.08 \pm 0.005$ & $0.10 \pm 0.005$ & $0.10 \pm 0.005$ \\
\hline & 3 & $0.08 \pm 0.006$ & $0.10 \pm 0.004$ & $0.10 \pm 0.005$ \\
\hline \multirow[t]{3}{*}{$h_{\mathrm{IO}}^{2}$} & 1 & $0.06 \pm 0.007$ & $0.07 \pm 0.005$ & $0.06 \pm 0.005$ \\
\hline & 2 & $0.07 \pm 0.007$ & $0.06 \pm 0.005$ & $0.05 \pm 0.005$ \\
\hline & 3 & $0.06 \pm 0.007$ & $0.06 \pm 0.005$ & $0.05 \pm 0.005$ \\
\hline \multirow{3}{*}{$r_{\mathrm{g} \text { NO IO }}$} & 1 & & & \\
\hline & 2 & $0.73 \pm 0.081$ & $0.74 \pm 0.051$ & $0.75 \pm 0.058$ \\
\hline & 3 & $0.74 \pm 0.080$ & $0.73 \pm 0.050$ & $0.74 \pm 0.059$ \\
\hline \multirow{3}{*}{ Repeatability $_{\mathrm{NO}}$} & 1 & & & \\
\hline & 2 & $0.12 \pm 0.006$ & $0.12 \pm 0.005$ & $0.12 \pm 0.005$ \\
\hline & 3 & $0.12 \pm 0.006$ & $0.12 \pm 0.004$ & $0.12 \pm 0.005$ \\
\hline \multirow[t]{3}{*}{ Repeatability $_{\mathrm{IO}}$} & 1 & & & \\
\hline & 2 & $0.11 \pm 0.007$ & $0.09 \pm 0.005$ & $0.08 \pm 0.004$ \\
\hline & 3 & $0.11 \pm 0.007$ & $0.08 \pm 0.006$ & $0.07 \pm 0.005$ \\
\hline
\end{tabular}

${ }^{a}$ (1) Univariate sire model on raw litter size, (2) bivariate animal model on raw litter size, (3) bivariate animal model on normal scores.

OIF, respectively, and 0.16, 0.09 and 0.04 in BMC, respectively).

\subsection{Genetic correlation between litter size after nat- ural and induced oestrus}

The genetic correlation between litter size after natural and induced oestrus was estimated with animal and sire model for the three breeds and by using different subsets of data. Whatever the data sets used, results were very stable and similar with values varying from 0.70 to 0.74 in $\mathrm{OIF}, 0.73$ to 0.76 in BMC and 0.74 to 0.79 in VEN (Table 4).

\section{Discussion and conclusion}

The higher variability of induced prolificacy compared to natural prolificacy observed in these three

Table 5

Heritability estimates and standard errors of litter size after natural $\left(h_{\mathrm{NO}}^{2}\right)$ and hormone-induced $\left(h_{\mathrm{IO}}^{2}\right)$ oestrus according to parities

\begin{tabular}{lllll}
\hline & & 1st lambing & 2nd lambing & 3rd lambing \\
\hline Ovin Ile de France & $h_{\text {NO }}^{2}$ & $0.10 \pm 0.02$ & $0.08 \pm 0.02$ & $0.09 \pm 0.02$ \\
& $h_{\text {IO }}^{2}$ & $0.12 \pm 0.05$ & $0.08 \pm 0.05$ & $0.05 \pm 0.02$ \\
Blanc du Massif & $h_{\text {NO }}^{2}$ & $0.17 \pm 0.02$ & $0.14 \pm 0.02$ & $0.10 \pm 0.01$ \\
Central & $h_{\mathrm{IO}}^{2}$ & $0.16 \pm 0.08$ & $0.09 \pm 0.04$ & $0.04 \pm 0.01$ \\
\hline
\end{tabular}


breeds agrees with previous studies on the same breeds as well as on other French breeds. This variability increase is larger than the scale effect due to the increase of mean prolificacy, as reported by Bodin and Elsen (1989). In natural oestrus, the increase of prolificacy with age is well known, but the effect of hormonal treatment with age is less well documented. Hormonal treatment seems to smooth the age effect. After induced oestrus, the mean prolificacy reaches a plateau earlier than after natural oestrus and the greatest increase occurs at a younger age.

The model describing natural or induced prolificacy includes fixed effects corresponding to correction factors used routinely in the French genetic evaluation of the prolificacy for meat sheep (year* flock* season of lambing effect, a combination of type of rearing, age at the first lambing, interval between lambings and number of lambs suckled at the previous lambing and the month of birth nested within gestation number), a permanent environmental effect associated with the ewe and the additive genetic effect (sire or animal effects). This model only explains $18 \%$ of the total variance. In order to improve the predictability of the model, other factors such as the number of lambs suckled at the previous lambing, the type of suckling of the ewe and the type of birth of the ewe could be included. These factors were tested in previous analyses but they are not taken into account in the genetic evaluation model because the estimated effects of these factors are difficult to interpret biologically. This arises because of confounding between positive genetic and negative non-genetic effects linked to these variation factors. For the French genetic evaluation, Poivey et al. (1990) chose to consider these effects only when the negative effect is large (i.e. the youngest ewes with a short post partum delay) by introducing a specific class in the "physiological condition" factor. Another factor such as the dose of PMSG administered could also be included in the genetic evaluation model. At the present time, this information is not recorded.

Different data sets were created in this study to estimate genetic parameters of the litter size after natural and induced oestrus. Several studies have shown that data structure (quality and quantity of data) and absence of connectedness can affect the estimation and the precision of genetic parameters. The results obtained in this study were very stable between data sets, which can be explained by a good connectedness between flocks and sufficient quantity of information.

The aim of this study was to obtain new estimates of genetic parameters for natural and induced prolificacy $\left(h^{2}, r_{\mathrm{g}}\right)$ in order to optimise the overall selection of the trait. Heritability estimated for all the lambings on natural oestrus (0.10) agreed with the results of recent studies (Janssens et al., 2004). Matos et al. (1997) found a heritability of 0.16 in Rambouillet and 0.08 in Finnsheep, and Altarriba et al. (1998) a heritability of 0.08 in Rasa Aragonesa. Only Lee et al. (2000) estimated a lower heritability (0.05) in Rambouillet. Repeatability of natural prolificacy was relatively low in our study and lower than that found by Janssens et al. (2004). However, our results were very stable with regard to the different breeds and data sets, even on the restricted data set with large families (40 daughters with at least 4 litters each). The estimates of heritability of induced oestrus also agreed with previous (Bodin, 1979) and recent results (Janssens et al., 2004), although for these last authors the values of heritability for induced oestrus were very similar to those for natural prolificacy. In our study, the heritability of induced prolificacy was slightly lower than that for natural prolificacy, mainly due to a higher residual variance.

The genetic correlation estimated in this paper $(0.75)$ was higher than the previous estimate $(0.40$ in Bodin, 1979) used in the current French genetic evaluation of prolificacy. However, this value (0.40) was estimated from only the first lambing of dairy Lacaune ewes with a simpler method based on the correlation between breeding values for each trait. This new estimate of the genetic correlation ( 0.75$)$ agreed with those Janssens et al. (2004) for the Texel and Suffolk breeds by using an animal REML model.

The stability of the estimates of genetic parameters (heritability, repeatability and genetic correlation) obtained in this study supports to take into account in the national evaluation program an unique model and an unique set of genetic parameters available for all the breeds. Despite the high genetic correlation estimates between natural and induced oestrus, a bivariate model must be considered to estimate breeding value for these two traits.

This study also underlined the fact that heritabilities of prolificacy on the first parity were higher than 
those estimated at an older age. This result agreed with the estimation of Gates and Urioste (1995) on Swedish ewes in which the heritability of prolificacy was higher at the first lambing and decreased thereafter. Nevertheless, Yazdi et al. (1999) and Lee et al. (2000) found that the heritability of the prolificacy increased from the first to the third lambing.

The value of the genetic correlation $\left(r_{\mathrm{g}}=0.75\right)$ will be changed in the computations of the breeding values and the determination coefficient of meat sheep. As beforehand, this parameter will be considered for all parities. But changes of heritabilities with age indicate that relationship between first and subsequent lambing should be carefully investigated. Due to very few first lambing after induced oestrus, this study was not possible with our data. Moreover, selection for the litter size is based on a synthetic breeding value combining the estimates of both breeding values weighed by coefficients. At the present time, these coefficients are the proportion of each reproduction type (natural or induced) in each breed. They should be changed according to the real economic weight of each reproduction in the selection objectives. Further studies and additional work are needed to answer these questions and to confirm these results.

\section{Acknowledgements}

The authors wish to thank the UPRa (Unite de Promotion et de sélection de la Race) of the Ovin Ile de France, Mouton Vendéen and Blanc du Massif Central breeds for providing the data set.

\section{References}

Altarriba, J., Varona, L., Garcia-Cortés, A., Moreno, C., 1998. Bayesian inference of variance components for litter size in Rasa Aragonesa sheep. J. Anim. Sci. 76, 23-28.
Bodin, L., 1979. Estimation des paramètres génétiques de la taille de portée des agnelles Lacaune après fécondation sur oestrus naturel et induit. Ann. Génét. Sél. Anim. 11 (4), 413-424.

Bodin, L., Elsen, J.M., 1989. Variability of litter size of French sheep breeds following natural or induced ovulation. Anim. Prod. 48, 535-541.

Gates, P.J., Urioste, J.I., 1995. Heritability and sire genetic trend for litter size in Swedish sheep estimated with linear and threshold models. Acta Agric. Scand. 45, 228-235.

Groeneveld, E., 1998. VCE4 User's Guide and Reference Manual, Version 1.3.

Institut de l'Elevage, 1995. CR no. 2316.

Institut National de la Recherche Agronomique, Institut de l'Elevage, France Upra Sélection, 2003. CR no. 3347.

Janssens, S., Vandepitte, W., Bodin, L., 2004. Genetic parameters for litter size in sheep after natural and hormone-induced oestrus. Genet. Sel. Evol. 36, 543-562.

Lee, J.W., Waldron, D.F., Van Vleck, L.D., 2000. Parameter estimates for number of lambs born at different ages and for 18month body weight of Rambouillet sheep. J. Anim. Sci. 78, 2086-2090.

Matos, C.A.P., Thomas, D.L., Gianola, D., Tempelman, R.J., Young, L.D., 1997. Genetic analysis of discrete reproductive traits in sheep using linear and nonlinear models: 1. Estimation of genetic parameters. J. Anim. Sci. 75, 76-87.

Patterson, H.D., Thompson, R., 1971. Recovery of interblock information when block sizes are unequal. Biometrika 58, $545-554$.

Poivey, J.P., Cournut, J., Jullien, E., Bibé, B., Perret, G., Elsen, J.M., Berny, F., Bouix, J., Bodin, L., 1990. Estimation des valeurs génétiques des reproducteurs ovins viande en France. FEZ, session 3.

Poivey, J.P., Jullien, E., Bibé, B., 1994. Utilisation du modèle animal chez les ovins allaitants. In: Foulley, J.L., Molenat, M. (Eds.), Séminaire Modèle Animal.

Poivey, J.P., Tiphine, L., Berny, F., Jullien, E., 1995. Indexation blup modèle animal chez les ovins allaitants. Renc. Rech. Ruminants 2, 453-456.

SAS Institute Inc., 1999. SAS/STATS User's Guide, Version 8. SAS Institute Inc., Cary.

Yazdi, M.H., Johansson, K., Gates, P., Näsholm, A., Jorjani, H., Liljedahl, L.-E., 1999. Bayesian analysis of birth weight and litter size in Baluchi sheep using Gibbs sampling. J. Anim. Sci. $77,533-540$. 